\title{
METODA GENEROWANIA MODELU DYNAMIKI STATKU POWIETRZNEGO ZASTOSOWANA W SYMULATORZE KABINY SAMOLOTU PASAŻERSKIEGO
}

\begin{abstract}
Modelowanie dynamiki lotu statku powietrznego jest procesem, w wyniku którego można uzyskać odpowiedź na pytania: jak zachowuje się badany statek powietrzny oraz jak należy nim sterować, aby wykonał przewidziane zadanie. W ramach prac prowadzonych w Zakładzie Awioniki i Uzbrojenia Lotniczego Wojskowej Akademii Technicznej zbudowano dydaktyczny symulator kabiny współczesnego samolotu pasażerskiego z zaimplementowanym modelem ruchu statku powietrznego. Oprócz symulacji pracy przyrządów pokładowych stanowisko może służyć do analizy wpływu poszczególnych parametrów geometrycznych, masowych i innych charakterystyk statku powietrznego na jego zachowanie. Dzięki temu możliwe jest podczas zajęć dydaktycznych przebadanie wielu konfiguracji samolotu bez rozwiązywania trudnych zagadnień matematycznych. Studenci mogą więc więcej czasu poświęcić na rozpatrywanie różnych przypadków i analizę jakościową na podstawie przeprowadzonego wirtualnego lotu.
\end{abstract}

Słowa kluczowe: dynamika lotu, statek powietrzny, symulator kabiny statku pasażerskiego

\section{Wprowadzenie}

Modelowanie dynamiki lotu statku powietrznego to zaawansowany proces, w wyniku którego można z dużym przybliżeniem określić zachowanie badanego obiektu pod wpływem wielu różnych czynników. Liczba i jakość otrzymanych wyników zależy przede wszystkim od wiedzy inżynierów zajmujących się tym zagadnieniem. Niezbędna jest znajomość mechaniki lotu, aerodynamiki, teorii sterowania oraz umiejętność posługiwania się zaawansowanym aparatem mate-

\footnotetext{
${ }^{1}$ Krzysztof Kaźmierczak, e-mail: krzysztof.kazmierczak@wat.edu.pl

2 Autor do korespondencji/corresponding author: Zdzisław Rochala, Wojskowa Akademia Techniczna, ul. S. Kaliskiego 2, 00-908 Warszawa, tel. (22)6839851, e-mail: zrochala@wat.edu.pl

${ }^{3}$ Konrad Wojtowicz, kwojtowicz@wat.edu.pl
} 
matycznym, dodatkowo wsparta doświadczeniem technicznym (rys. 1.). Uzyskane podczas modelowania efekty są wykorzystywane jako wsparcie podczas projektowania nowego statku powietrznego, systemu sterowania czy w trakcie budowania odpowiedniego symulatora lotu. Wykonane stanowiska symulacyjne są następnie wykorzystywane podczas szkolenia załóg lub w celach dydaktycznych na uczelniach o profilu lotniczym. Umożliwia to zapoznanie się ze specyfiką wybranego statku powietrznego, z jego wyposażeniem pokładowym i zachowaniem w powietrzu oraz ze sposobem sterowania mimo braku dostępu do rzeczywistego obiektu.

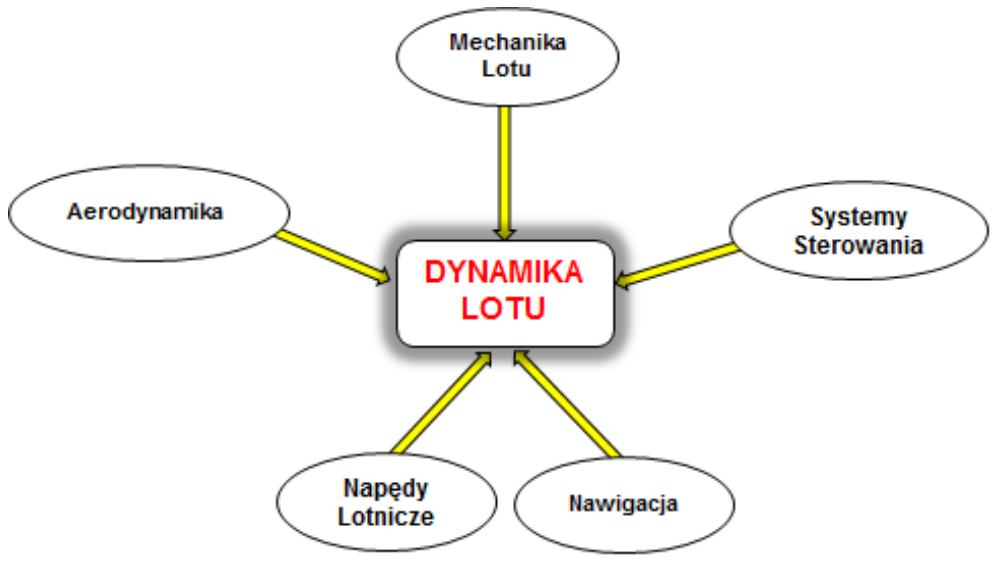

Rys. 1. Zakres wiedzy wykorzystywany w procesie modelowania dynamiki ruchu statku powietrznego

Fig. 1. Technical knowledge employed in the dynamic modeling process of an airliner

\section{Stanowisko symulatora kabiny samolotu pasażerskiego}

W ramach prac prowadzonych w Zakładzie Awioniki i Uzbrojenia Lotniczego Wojskowej Akademii Technicznej [1] zbudowano dydaktyczny symulator kabiny współczesnego samolotu pasażerskiego Boeing 737 NG (rys. 2.). Podstawę konstrukcji symulatora kokpitu stanowi replika kabiny wykonana przez producenta tego typu elementów. Wszystkie części składowe kabiny zostały wykonane w skali 1:1 z dużą dbałością o szczegóły. Wszelkie napisy i inskrypcje na panelach i klawiszach przycisków odpowiadają formą i umiejscowieniem rzeczywistym odpowiednikom. Zbudowany kokpit symulatora składa się z konstrukcji nośnej, panelu centralnego z otworami pod monitory oraz z konstrukcji do montażu pulpitów (ang. glareshield) sterujących dla autopilota i EFIS. 
Rys. 2. Stanowisko symulatora kabiny samolotu pasażerskiego Boeing $737 \mathrm{NG}$

Fig. 2. The simulation station of Boeing 737 NG airliner cockpit

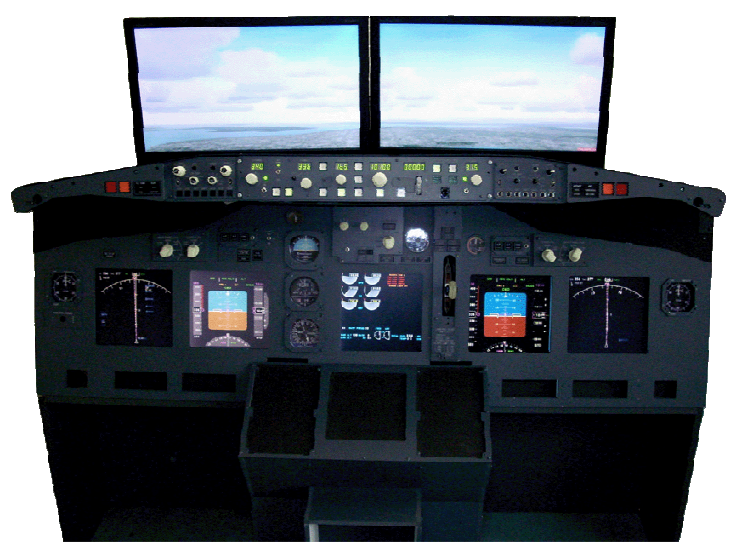

Głównym kryterium branym pod uwagę podczas budowy stanowiska symulatora było wykonanie trwałych podzespołów, tak aby nie ulegały one mechanicznym uszkodzeniom podczas intensywnego użytkowania $\mathrm{w}$ trakcie zajęć dydaktycznych. Dlatego najkorzystniejszym rozwiązaniem było opracowanie płytek drukowanych pod obwody elektroniczne modelowanych pulpitów kontrolnych. Na podstawie opracowanej dokumentacji [2] dla poszczególnych paneli zaprojektowano schematy elektryczne wybranych pulpitów i komplety płytek drukowanych dla paneli EFIS i panelu Autopilota [3]. Podczas prób dopasowania do zaprojektowanych płytek drukowanych elementów elektronicznych okazało się, że niektóre $\mathrm{z}$ nich, zwłaszcza wykorzystywane do obsługi wyspecjalizowanych funkcji, nie są dostępne w sprzedaży. $\mathrm{Z}$ tego względu należało samodzielnie wykonać podobne elementy, przerabiając te, których zakup był możliwy. W ten sposób powstał m.in. współosiowy przełącznik wielofunkcyjny zamontowany w zestawie panelu EFIS. Ostatecznie każde urządzenie zastosowane do budowy symulatora kabiny składa się z repliki pulpitu wykonanego z pleksi, kompletu niezbędnych płytek pod obwody elektroniczne i grupy zamontowanych podzespołów elektronicznych (rys. 3.).

Bardzo ważnym etapem budowy symulatora było wykonanie i uruchomienie interfejsu elektronicznego (rys. 4.), umożliwiającego podłączenie elementów manipulacyjnych i sygnalizacyjnych $\mathrm{z}$ komputerem wyposażonym $\mathrm{w}$ oprogramowanie bazowe symulatora. Podstawę tego rozwiązania stanowi moduł interfejsowy FSCom. Tworzy on elektroniczną magistralę służącą do dwukierunkowej transmisji danych z wykorzystaniem interfejsu RS232 pomiędzy elementami wykonawczymi systemu a komputerem, na którym uruchomiono oprogramowanie symulatora. Współpracują z nim dwa moduły interfejsowe: FSDio oraz FSDisp (nazwy modułów przyjęto w zależności od pełnionych przez nie funkcji). Moduł FSDio (ang. Digital Input/Output) obsługuje różnego rodzaju przełączniki (stabilne, niestabilne, wielopołożeniowe, enkodery obrotowe), diody LED i wskaźniki analogowe. Moduł FSDisp (ang. Digital Display) obsługuje 
wyświetlacze 7-segmentowe w różnych konfiguracjach (3, 4, 5 lub 6 cyfr) i umożliwia wyświetlenie informacji przekazywanej załodze.

a)

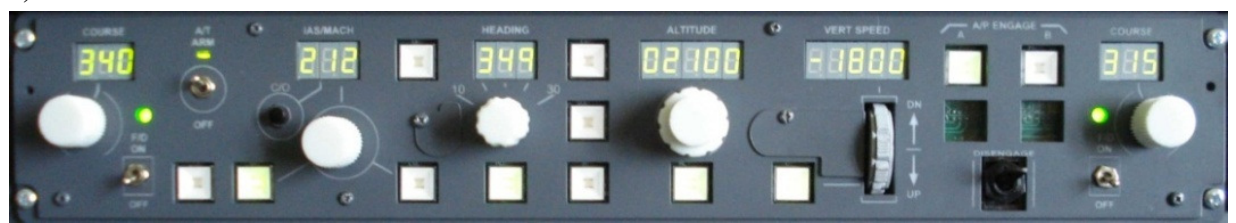

b)

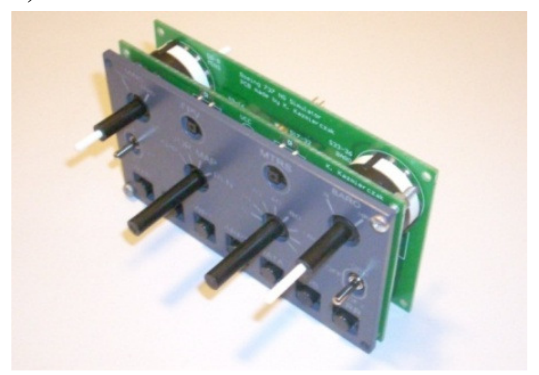

Rys. 3. Repliki zmontowanych i gotowych do użycia pulpitów: a) autopilota, b) EFIS

Fig. 3. Replicas of assembled and ready-to-use control desks: a) autopilot, b) EFIS

a)

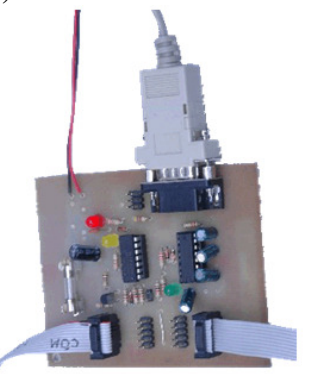

b)

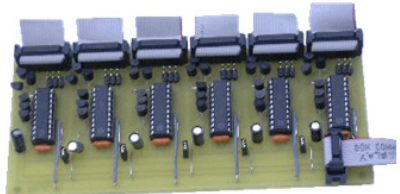

c)

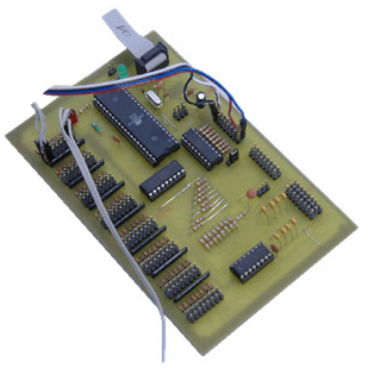

Rys. 4. Moduły interfejsu elektronicznego: a) FSCom, b) FSDio, c) FSDisp

Fig. 4. Modules of electronic interface: a) FSCom, b) FSDio, c) FSDisp

Drugą częścią prac przy symulatorze była realizacja interfejsów graficznych. Uzyskane wyniki pozwalają na wyświetlanie na ekranach komputerów przyrządów pokładowych. W zbudowanym stanowisku są dostępne monitory: PFD (ang. Primary Functions Display) i ND (ang. Navigation Display) montowane po dwa - dla kapitana i pierwszego oficera oraz monitor systemu EICAS (ang. Engine Indicating \& Crew Alerting System) w konsoli centralnej [4]. $\mathrm{Na}$ ekranach graficznych jest wyświetlana informacja o parametrach lotu, infor- 
macje nawigacyjne oraz informacje o bieżącej konfiguracji samolotu w czasie lotu. Każda zmiana położenia manipulatorów zamontowanych na pulpitach kontrolnych powoduje odpowiednią zmianę na wyświetlaczach.

Podstawą oprogramowania, na podstawie którego funkcjonuje zbudowany symulator, jest Microsoft Flight Simulator [5]. Wykorzystanie tego oprogramowania stało się możliwe poprzez zastosowanie specjalnego modułu software tworzącego dodatkowe środowisko wirtualnego lotu. W trakcie pracy programu można wydobyć z pamięci komputera informacje o bieżących parametrach lotu (np. wysokość, prędkość, położenie geograficzne, stan techniczny systemów pokładowych). Uzyskiwane w ten sposób dane o parametrach lotu - do obsługi elektronicznych wskaźników obrazowych oraz po konwersji na sygnały elektryczne, mogą być wykorzystywane do sterowania elektroniką pulpitów sterujących. W używanym oprogramowaniu dostępnych jest wiele gotowych modeli statków powietrznych. Każdy z nich jest zdefiniowany za pomocą kilku plików odpowiedzialnych za model 3D samolotu, jego wygląd zewnętrzny zbudowany z tekstur, wyposażenie pokładowe, dźwięki itp. Jednak najważniejsze dane opisujące parametry geometryczne, pilotażowe i charakterystyki aerodynamiczne statku powietrznego są zapisane $\mathrm{w}$ dwóch podstawowych plikach aircraft.air i aircraft.cfg.

\section{Metoda generowania modelu dynamiki statku powietrznego do stanowiska symulatora}

Wykorzystując zbudowane stanowisko symulatora lotu, opracowano metodę modelowania dynamiki lotu statku powietrznego, którą można przeprowadzić i zademonstrować podczas zajęć dydaktycznych ze studentami. Zaleta proponowanej metody polega na tym, że za pomocą specjalnego oprogramowania można zbudować wirtualny trójwymiarowy model graficzny dowolnego obiektu latającego oraz wygenerować pliki determinujące dynamikę lotu obiektu na podstawie wprowadzonych parametrów prędkościowych, geometrycznych i masowych. Uruchomienie symulatora $\mathrm{z}$ tak przygotowanymi danymi początkowymi pozwala na realizację wirtualnego lotu i ocenę zachowania się danego obiektu w przestrzeni. Budowę nowego modelu statku powietrznego do stanowiska symulatora lotu należy rozpocząć od wykonania modelu 3D. Na podstawie dokumentacji technicznej lub fotograficznej i wyznaczonych wielkości geometrycznych rzeczywistego statku powietrznego za pomocą oprogramowania GMAX można opracować bryłę samolotu, która może być zaimplementowana do środowiska symulacyjnego symulatora lotu (rys. 5.). Następnym i najważniejszym krokiem jest przygotowanie plików aircraft.cfg i aircraft.air. Zawierają one ustawienia samolotu i charakterystyki aerodynamiczne używane do obliczeń w środowisku oprogramowania Microsoft Flight Simulator. Uzyskuje się je, wprowadzając do aplikacji AirWrench [6] parametry modelowanego statku powietrznego. 
a)

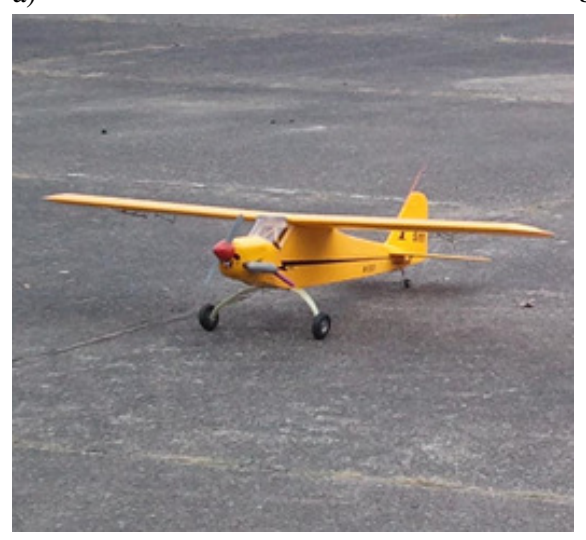

b)

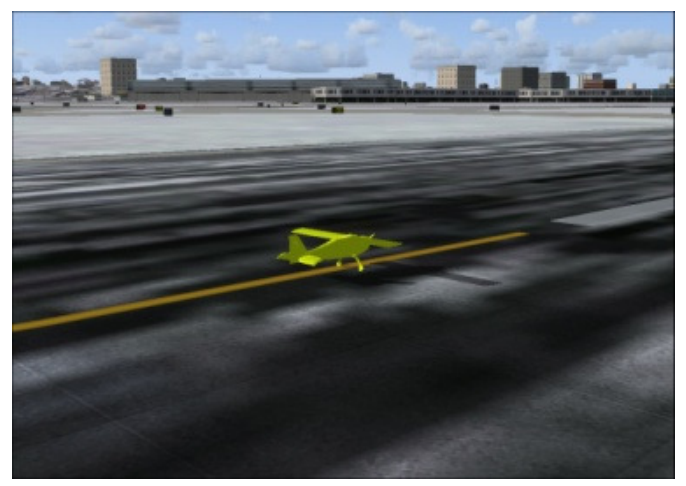

Rys. 5. Modelowany samolot UAV Piper: a) widok rzeczywisty, b) model wirtualny utworzony w środowisku Microsoft Flight Simulator

Fig. 5. Modeled UAV Piper aircraft: a) real view, b) a virtual model created by using Microsoft Flight Simulator environment

Interfejs aplikacji AirWrench jest zbudowany z głównego okna graficznego zawierającego interaktywne pola edycyjne i dialogowe oraz z paska zakładek, których wybór ma wpływ na wyświetlane treści. Po uruchomieniu aplikacji na ekranie jest wyświetlana zawartość zakładki Specs. Zawiera ona podstawowe funkcje edycyjne, takie jak: wybór pliku z rozszerzeniem .air, na którym będą wykonywane operacje, uruchomienie trybu edycyjnego i ustalenie używanych jednostek metrycznych. W pozostałych polach ustala się ogólną specyfikację projektowanego modelu samolotu, czyli przede wszystkim limity prognozowanych prędkości maksymalnych i minimalnych w różnych etapach lotu. Wymiary geometryczne opisujące rozmiary liniowe oraz powierzchnie poszczególnych obszarów konstrukcji otrzymane na podstawie rysunków przekrojowych, zrobionych zdjęć czy też przygotowanego wcześniej modelu 3D statku powietrznego należy wprowadzić do zakładki Dimensions. W pola edycyjne wpisuje się długość samolotu, rozpiętość jego skrzydeł wraz z ich powierzchnią i kątem wzniosu oraz odległość pomiędzy krawędzią natarcia i krawędzią spływu w miejscu styku skrzydła z kadłubem. W dolnej części ekranu należy uzupełnić dane dotyczące powierzchni stateczników oraz sterów kierunku i wysokości oraz maksymalne wartości odchylenia wszystkich powierzchni sterowych. Informacje te służą do estymowania współczynników stabilności i sterowalności, które są zapisywane w pliku z rozszerzaniem .air.

Zakładka Systems służy do konfiguracji klap, spojlerów, podwozia i systemu autopilota. Podczas projektowania modelu bezpilotowego statku powietrznego w oknie tym skorzystano jedynie z opcji ustalenia siły hamulca parkingowego celem ułatwienia korzystania z gotowego obiektu w środowisku oprogramowania Microsoft Flight Simulator. W kolejnej zakładce program AirWrench 
pozwala na estymację prędkości wznoszenia, przechylania oraz odchylania w całym zakresie prędkości lotu, a wynik zostaje uwidoczniony na wykresach. W oknie tym również można dostosować efektywność działania lotek. Następnie ustalane są parametry silnika, takie jak: liczba cylindrów, pojemność, stopień sprężania, obroty minimalne i maksymalne oraz moc. Druga część okna dotyczy śmigła, które opisane jest z wykorzystaniem takich parametrów, jak: średnica śmigła, materiał wykonania czy też liczba łopat.

Zakładka Fuel umożliwia prezentację i edycję lokalizacji oraz pojemności zbiorników paliwa. Pozwala to na ustalenie wpływu zbiorników paliwa na środek ciężkości samolotu. Dodatkowo można w niej ustalić lokalizację silników w budowanym modelu samolotu. Ich ustawienie ma bardzo duży wpływ na parametry statku powietrznego. Okna edycyjne w zakładce Weight służą do ustalenia rozmieszczenia i mas ładunków znajdujących się na statku powietrznym. Na 16 pozycjach można rozdysponować dodatkowe obciążenia wzdłuż całej długości i rozpiętości samolotu. W pozostałych oknach ustala się bazową i dopuszczalną wagę obiektu. W zakładce Balance jest przedstawiony piktogram opracowywanego modelu. Wirtualną reprezentację obiektu uzyskuje się na podstawie wprowadzonych danych do zakładki Dimensions. Zarys samolotu jest skalowany i odwzorowuje wszystkie wprowadzone wymiary. Obrazek pozwala zorientować się, gdzie są zlokalizowane środek ciężkości CoG (ang. Center of Gravity), środek parcia CoL (ang. Center of Lift), średnia cięciwa aerodynamiczna MAC (ang. Mean Aerodynamic Chord), podwozie i powierzchnia ogonowa.

Zakładka Contacts umożliwia wyświetlenie i edycję do 16 punktów kontaktowych budowanego modelu. Element ten pozwala w prosty sposób ustalić miejsca przylegania podwozia samolotu do ziemi, czas potrzebny na jego wypuszczenie i maksymalne prędkości, przy których może być ono wysunięte. Dodatkową opcją jest możliwość rozmieszczenia oświetlenia (np. światła nawigacyjne) na powierzchni modelowanego statku powietrznego. Zakładka Tuning składa się z suwaków służących do finalnego dostrajania dynamiki statku powietrznego. Okno wyboru typu samolotu Aircraft Type pozwala wygenerować domyślne parametry dla określonego typu statku powietrznego, a okno FS Version służy do ustalenia wersji oprogramowania, do której będzie zaimplementowany nowy plik z rozszerzeniem .air. Ostatecznie w zakładce Air Foils można obejrzeć dane dotyczące profilu aerodynamicznego skrzydła zarówno w formie tekstowej, jak i graficznej.

Wynikiem przejścia przez wszystkie etapy wypełniania pól edycyjnych $\mathrm{w}$ oprogramowaniu AirWrench są dwa pliki $\mathrm{z}$ rozszerzeniami air i .cfg, w których są zapisane wszystkie parametry opisujące dynamikę statku powietrznego. Końcowym etapem przedstawionej metody generowania modelu dynamiki wybranego statku powietrznego jest umieszczenie plików otrzymanych z programu GMAX i aplikacji AirWrench w jednym katalogu po to, aby pliki te były dostępne w środowisku programu Microsoft Flight Simulator. Tak przygotowa- 
ny kompletny model samolotu może być wybrany z poziomu głównego menu oprogramowania symulatora.

\section{Wnioski}

Zbudowany model samolotu charakteryzuje się wyglądem zewnętrznym odpowiadającym rzeczywistemu statkowi powietrznemu oraz zachowaniem w atmosferze adekwatnym do wprowadzonych wcześniej ustawień w plikach z rozszerzeniami .air i .cfg. Wykorzystując wirtualne zobrazowanie środowiska ruchu i wskaźniki graficzne stanowiska symulatora kabiny, można na bieżąco obserwować i analizować lot tak powstałego wirtualnego samolotu (rys. 6.).

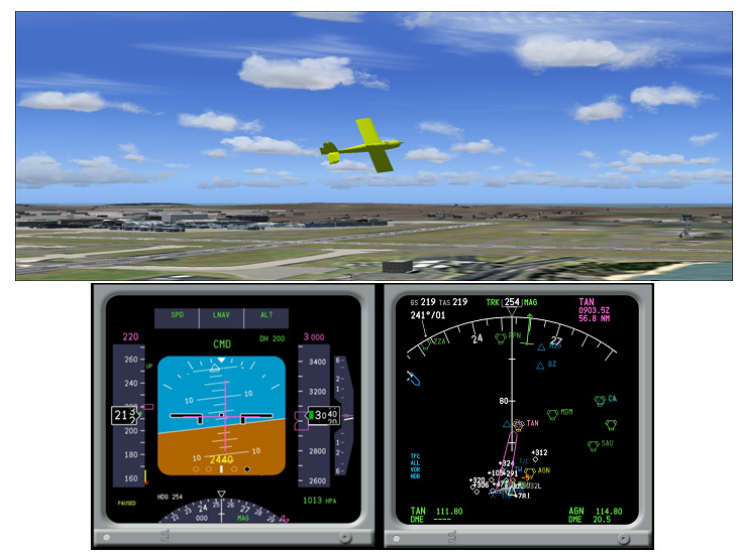

Rys. 6. Model samolotu i środowiska ruchu symulatora oraz formy graficzne parametrów pilotażowych i nawigacyjnych prezentowanych na wskaźnikach PFD i ND

Fig. 6. The aircraft model, the simulator environment and graphical forms of pilotage and navigational parameters presented on PFD and ND displays

Sterowanie takim obiektem może być realizowane (oprócz joystickiem) za pomocą panelu autopilota, a ustawienia i treści graficzne wskaźników PFD i ND mogą być zmieniane za pomocą panelu kontroli EFIS. Przeprowadzone badania weryfikacyjne potwierdziły przydatność i skuteczność proponowanej metody modelowania dynamiki lotu statku powietrznego w dydaktyce, a wykorzystanie stanowiska symulatora kabiny pozwala dodatkowo w przystępny sposób badać i obserwować wpływ dynamiki wybranego statku powietrznego na jego charakterystyki pilotażowe.

\section{Literatura}

[1] Dębski P., Kaźmierczak K., Rochala Z.: Symulator kabiny samolotu pasażerskiego BOEING 737NG. XI Międzynarodowa Konferencja „Komputerowe Systemy Wspomagania Nauki, Przemysłu i Transportu" TRANSKOMP 2007, t. I. ZPITE, Radom 2007.

[2] The Boeing Company: 737-600/-700/-800/-900 Operations Manual, The Boeing Company 2002. 
[3] Kaźmierczak K.: Projekt interfejsu sprzętowego do współpracy z oprogramowaniem symulatora lotu. WAT, Warszawa 2008 (praca niepublikowana).

[4] Kathy H.A.: Avionics handbook. CRC Press LLC, 2001.

[5] Williams B.: Microsoft flight simulator as a training aid. Aviation Supplies \& Academics Inc., January 1, 2007.

[6] Beckwith G.W.: AirWrench user's guide. AirWrench, 2004-2010, GWBeckwith.

\title{
GENERATION METHOD OF AIRCRAFT DYNAMIC MODEL EM- PLOYED IN THE AIRLINER COCKPIT SIMULATOR
}

\begin{abstract}
A bstract
Aircraft flight dynamic modeling is a process that is used to find answers to questions: what is the aircraft's behavior and how it must be guided to accomplish the objectives. During works conducted at Faculty of Avionics and Air Armament at Military University of Technology, the didactic modern airliner flight deck simulator, with implemented appropriate flight model, was developed. In addition to instrument panel simulation, this simulator can be used as a stand for analysis of geometric, mass and different parameters impact on aircraft behavior. Due to that, it is possible to investigate many aircraft configurations without the need of solving mathematical equations, during didactic trainings. Students can have some additional time to consider different problematic cases and qualitative analysis on the basis of virtual flights.
\end{abstract}

Keywords: flight dynamics, aircraft, airliner cockpit simulator

DOI:10.7862/rm.2013.40

Otrzymano/received: $15.09 .2013 \mathrm{r}$.

Zaakceptowano/accepted: 22.11.2013 r. 